\title{
Determination of reinforcing bars for tests of hollow core slabs with continuity
}

\section{Determinação da armadura negativa para ensaios de lajes alveolares com continuidade}
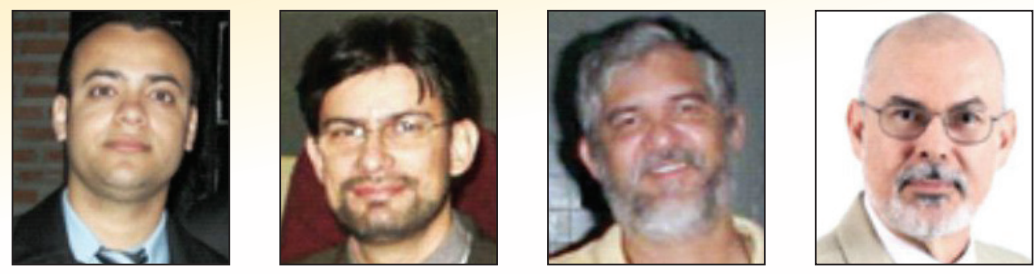

A. P. SANTOS a andreiltonsantos@yahoo.com.br

M. A. FERREIRA b marcelo@power.ufscar.br

R. C. CARVALHO chust@power.ufscar.br

L. M. PINHEIRO a libanio@sc.usp.br

\begin{abstract}
The structural designs of floors formed by hollow core slabs usually consider these as simply-supported slabs. In recent years there have been project changes and hollow core slabs with continuity are widely used. The objective of this study is to suggest a way to calculate the reinforcement bars to be used in tests with continuity provided by a structural topping. Thus, this paper presents a method based on the maximum positive resistance moment and maximum shear strength of a hollow core slab. The method is applied to a test in hollow core slab specimens which have the following dimensions: $2 \mathrm{~m}$ width, $6 \mathrm{~m}$ long, and $21 \mathrm{~cm}$ high. The results indicated that the method was satisfactory to the performed test, and can therefore be applied to the other test configurations or even designs.
\end{abstract}

Keywords: hollow core slab, continuity, reinforcing bars, topping, tests.

\section{Resumo}

Os projetos estruturais de pavimentos formados por lajes alveolares usualmente as consideram como simplesmente apoiadas. Nos últimos anos têm ocorrido modificações nos projetos, de tal forma que lajes alveolares com continuidade têm sido muito utilizadas. O objetivo deste trabalho é sugerir uma forma de se calcular a armadura negativa para ser utilizada em ensaios com continuidade obtida por meio de uma capa estrutural. Para isso, apresenta-se um método baseado no máximo momento resistente positivo e na máxima força cortante resistente de uma laje alveolar. O método é aplicado a um ensaio em lajes alveolares com as seguintes dimensões: $2 \mathrm{~m}$ de largura, $6 \mathrm{~m}$ de comprimento e $21 \mathrm{~cm}$ de altura. Os resultados indicaram que o método foi satisfatório para o ensaio realizado e, portanto, pode ser aplicado para outras configurações de ensaio, ou até mesmo em projetos.

Palavras-chave: laje alveolar, continuidade, armadura negativa, capa estrutural, ensaios. 


\section{Introduction}

The hollow core slabs were developed in the 1950s in the United States of America and in Europe on account of the production progress in concrete technology and also the increased use of long-line prestressed system. This type of structure is known for providing economic flooring and covering systems,
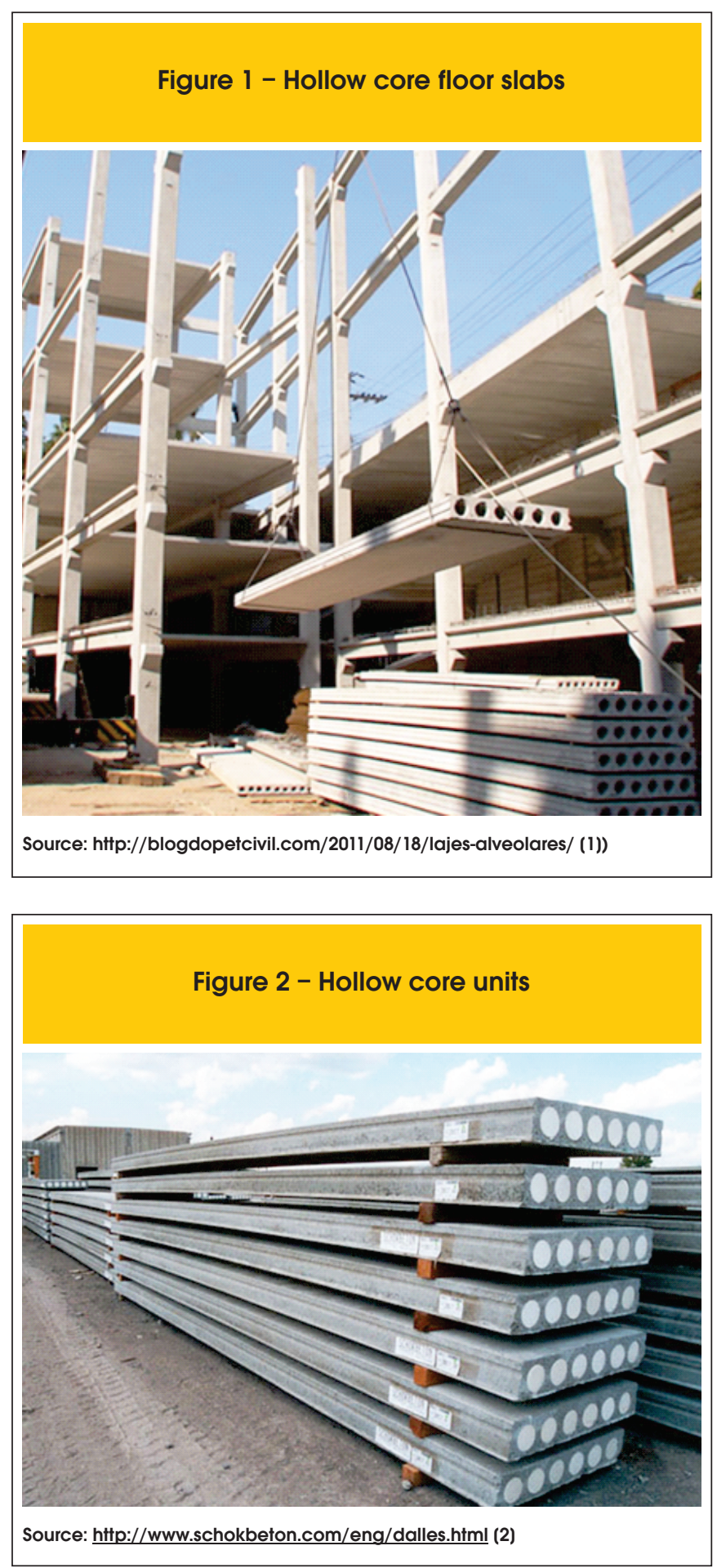

high speed assembly, small number of elements and low selfweight. It is estimated that the self-weight of a hollow core unit is about half the size of a solid section of the same height. Figure 1 shows an example of hollow core slab floors, Figure 2 presents examples of hollow core units, and Figure 3 displays a typical cross section.

Structurally, the hollow core slabs provide the efficiency of a prestressed element, reaching considerable spans with high load bearing capacity and small displacements. Moreover, if properly designed and detailed, they help to distribute the horizontal loads through the floor diaphragm effect.

Another important benefit of the hollow core slabs is fire resistance. According to $\mathrm{PCl}$ [3] a hollow core panel can resist up to four hours when subjected to high temperatures. This resistance depends on the height of the element and also on the cover of the reinforcement.

Usually these slabs are designed assuming simple supports. This happens because they are prestressed elements in which pretensioning is used, with the prestressed tendon placed near the bottom face. This provides the slabs high load bearing capacity, large spans, and small displacements.

However, a connection between two hollow core slabs can be implemented to ensure the negative moment resistance. This is called continuity.

This continuity can be made by placing reinforcement bars over the supports, inside the cover (Figure 4), or in openings made in the cores (Figure 5), in the regions of negative bending moment.

Figure 3 - Typical cross section of hollow core slabs

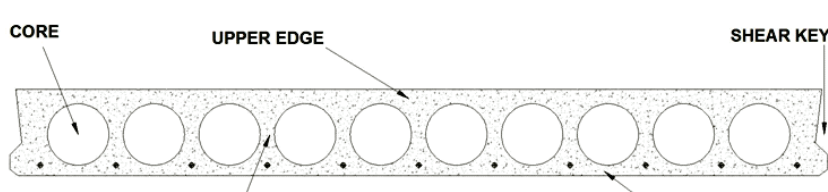

RIB

LOWER EDGE

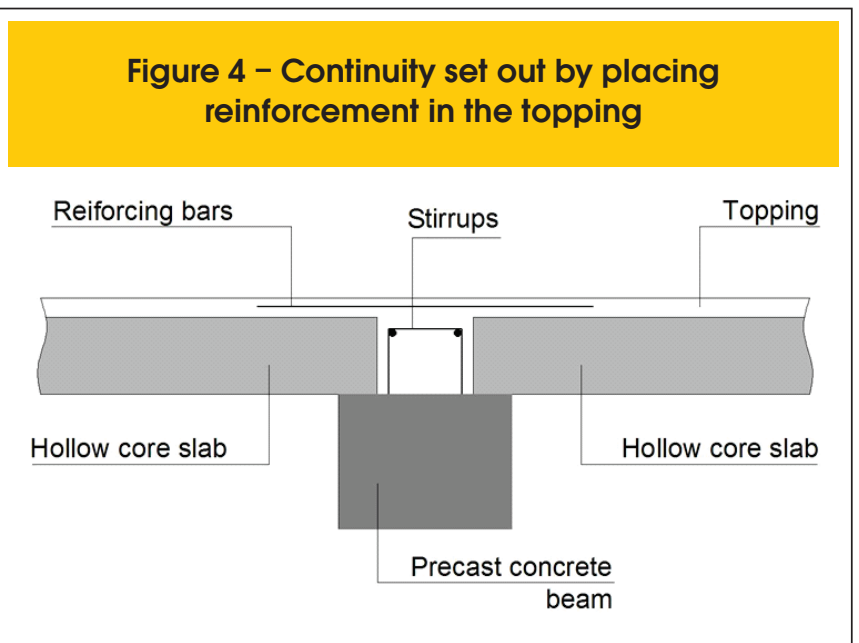




\subsection{Tests of hollow core slabs}

Experimental analysis of hollow core slabs have been carried out in several research centers worldwide in order to study their behavior alone or together. The main subjects studied are: shear and bending.

Bending tests can be made according to the FIP guidelines [4] A rigid beam should be used to transfer the force to the slab, for example a steel beam. The rigid beam has the purpose to ensure a uniform load distribution over the entire width of the slab. This steel beam must have a minimum height of $15 \mathrm{~cm}$, and $25 \mathrm{~cm}$ of height is indicated for tests using a hydraulic jack. The force is applied in the middle of the span, as shown in Figure 6. The standard test can be used to evaluate the shear strength of the slab, also suggested in the FIP guidelines [4]. The scheme of this test is similar to that presented for bending tests (Figure 6 ). However, the rigid beam must be positioned near one of the supports, at a distance of two and a half times the slab height. Rigid beams are also used in tests of hollow core slabs with continuity in order to simulate a transversal linear load in the center of the each slab, characterizing a bending test. Figure 7 presents a schema for continuous slabs test, with the instrumentation used in this work.

\subsection{Justification}

In Brazil, many buildings made with precast concrete have their floors constructed with hollow core slabs, commonly using topping to solidify the slabs. In these cases the use of top reinforcement over the supports is common. However, this reinforcement is not always considered in order to take the continuity in account. Therefore, it is important to analyze continuity in floors with hollow core slabs in which the materials and structural elements are used according to the Brazilian reality.

\subsection{Objective}

The objective of this work is to determine a methodology to calculate the negative reinforcement to be used in the experimental analyses, on full-scale test, of hollow core slabs with continuity

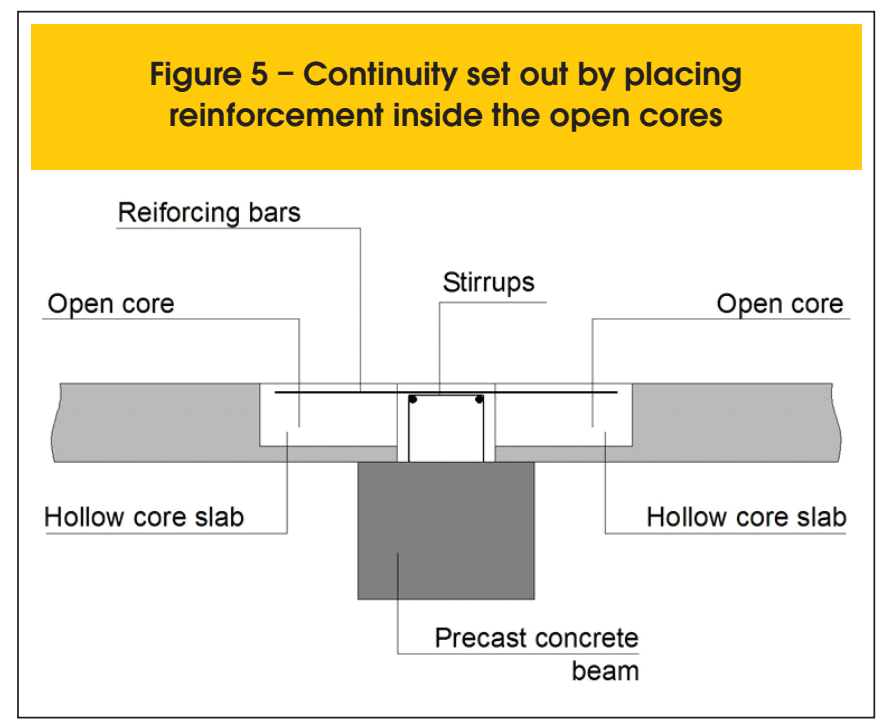

by adding the reinforcement bars inside the topping (Figure 4). This methodology can be employed in customary design situations, provided it is appropriately adapted.

\subsection{Methodology}

This method includes discussing the theories, present the deductions and use the equations necessary to obtain the negative reinforcement. Furthermore, to analyze its performance in a test considering the self-weight and two concentrated loads, one for each span.

\section{Advantages to promote continuity}

Some technical papers on continuity demonstrate approaches to obtain benefits when performing continuity. Table 1 describes these advantages.

In the structural design of these elements, each benefit should be taken into consideration according to the aspects of the project. However, with regards to the experimental analysis, of the three advantages cited in Table 1, the most plausible situation that can be analyzed and controlled in the laboratory is the first one. Therefore, comparative tests between the simple support situation and with continuity can be made for a single element, in other words, with the same geometry and materials, the same amount of prestressing bars $\left(A_{p}\right)$ and the same span $(\ell)$.

\section{Changes in the structural system}

The design of a hollow core slab considering continuity

\section{Figure 6 - Schema of bending test for single slabs} (Adapted from: COSTA (5))

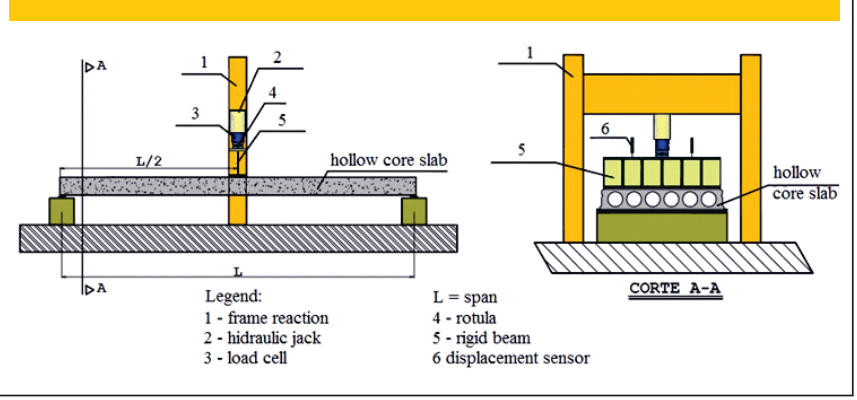

\section{Figure 7 - Schema of bending test for continuous slabs}

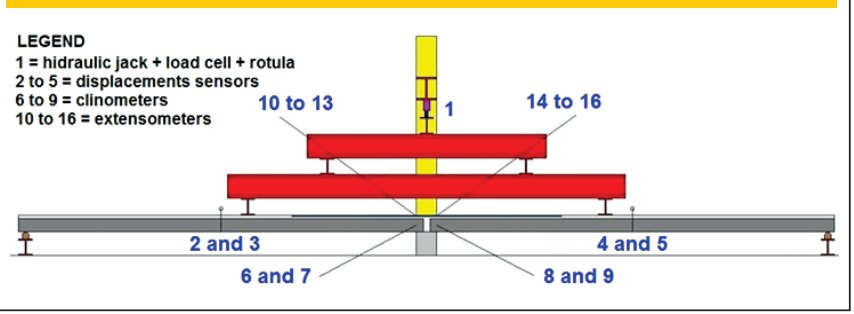


Table 1 - Advantages of using continuity. Comparison with the simply supported condition

\begin{tabular}{|c|c|c|}
\hline Advantages & References & Comments \\
\hline $\begin{array}{l}\text { Increased capacity to } \\
\text { withstand loads }\end{array}$ & $\begin{array}{l}\text { RESENDE and } \\
\text { GASTAL (6); } \\
\text { BARBIERI and } \\
\text { GASTAL (7) }\end{array}$ & $\begin{array}{l}\text { The increased capacity to withstand loads is the first } \\
\text { advantage perceived. It is the main advantage mentioned } \\
\text { in the international codes. It was confirmed in tests } \\
\text { conducted by the authors. E.g.: given a hollow core slab with } \\
\text { geometry and materials determined, also for a certain span } \\
\text { and amount of prestressing bars } \mathrm{A}_{\mathrm{p}} \text {, this slab can withstand } \\
\text { more loads with continuity, when compared to the simple } \\
\text { support condition. }\end{array}$ \\
\hline Increase in span & TAN et al. (8) & $\begin{array}{l}\text { E.g.: given a hollow core slab with geometry and materials } \\
\text { determined, also for a given load and amount of prestressing } \\
\text { bars } A_{p} \text {, this slab can achieve a larger span with continuity, } \\
\text { when compared to the simple support condition. }\end{array}$ \\
\hline $\begin{array}{l}\text { Decrease the amount } \\
\text { of prestressing } \\
\text { reinforcement }\left(A_{p}\right)\end{array}$ & $\begin{array}{l}\text { PETRUCELLI and } \\
\text { CARVALHO (9) }\end{array}$ & $\begin{array}{l}\text { E.g.: given a hollow core slab with geometry and materials } \\
\text { determined, also for a given load and for a certain span, this } \\
\text { slab requires a smaller amount of prestressing bars } A_{p} \text { with } \\
\text { continuity, when compared to the simple support condition. }\end{array}$ \\
\hline
\end{tabular}

must be obey the two phases described below:

- The first one corresponds to the simply supported slab condition. At this phase the self-weight of the precast slab has an effect $\left(g_{1}\right)$ and also the weight of the concrete cast in situ $\left(g_{2}\right)$, corresponding to the topping. The slab must resist the positive moment in the middle of the span. This first phase occurs during the continuity test;

- The second phase corresponds to connection with continuity and the emergence of rigid support. In this case, the positive moment is the sum between the positive moment obtained in the first phase and related to the second phase, in which the other dead loads $\left(g_{3}\right)$ and the live loads $(q)$ act. Consequently, the maximum negative moment is that calculated for the second phase, with the dead and live loads in the most unfavorable conditions. In the continuity test the second phase is represented by the hydraulic jack and the self-weight of the steel beams used to promote the load.

\section{Determination of the continuity reinforcement bars}

The design of a hollow core slab, taking into account continuity, can be made according to the model proposed by PETRUCELLI [10], adding one step that consist in calculating the continuity reinforcement bars $\left(A_{s}\right)$. It must also consider the change in the structural system discussed in section 3 .

As mentioned earlier, these reinforcement bars can be obtained considering the full action of the theoretical negative moment, commonly denominated as elastic moment. Furthermore, $A_{s}$ can be calculated taking into account a fraction of this moment.

However the negative bending moment depends on the value of the applied load. As this is a variable in the experimental analysis, the question is how to determine the amount of reinforcement bars $\left(A_{s}\right)$, for the experimental analyses, corresponding to $100 \%$ of continuity.

To solve that question it is necessary to set a criterion and through this obtain the reinforcement $A_{s}$ corresponding to $100 \%$ of continuity. One possible criterion is to consider the maximum resistance positive moment of the prestressing bars $\left(A_{p}\right)$ and then analyze the maximum shear resistance of hollow core slabs to be tested.

\subsection{Maximum resistance positive moment}

To understand the criterion of the slab's maximum positive resisting moment is required to use a hypothetical bending test with a

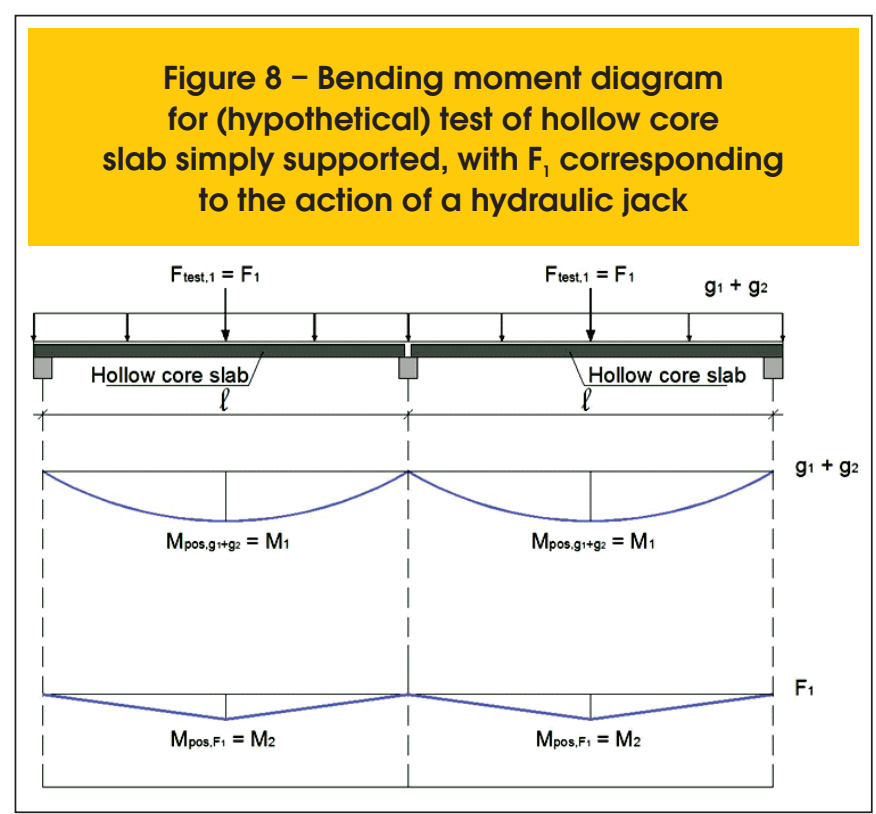




\section{Table 2 - Equations for calculating of hollow core slabs simply supported}

\begin{tabular}{|c|c|c|}
\hline Variable & Equation & Comments \\
\hline$M_{\text {pos,tot, } 1}$ & $\mathrm{M}_{\text {pos,tot }, 1}=\mathrm{M}_{\mathrm{R}}$ & $\begin{array}{c}\text { Deduced by balancing the section for simple bending. } \\
\text { It uses the inverse calculation using } A_{p} \text { of the hollow } \\
\text { core slab under consideration }\end{array}$ \\
\hline $\mathrm{M}_{1}$ & $M_{1}=\frac{\left(g_{1}+g_{2}\right) \cdot 1^{2}}{8}$ & See Figure 8 \\
\hline $\mathrm{M}_{2}$ & $M_{2}=M_{\text {pos,tot }, 1}-M_{1}$ & See Figure 8 \\
\hline$F_{1}$ & $M_{2}=\frac{F_{1} \cdot l}{4} \Rightarrow F_{1}=\frac{4 \cdot M_{2}}{l}$ & See Figure 8 \\
\hline
\end{tabular}

simply supported slab. Figure 8 shows the structural scheme of this test highlighting the bending moment diagrams due to selfweight of the slab $\left(g_{1}\right)$ and the weight of the topping $\left(g_{2}\right)$ and later due to the action of the hydraulic jack $\left(\mathrm{F}_{1}\right)$.

Therefore, considering a hollow core slab element with the geometry and materials characteristics, also prestressing bars $\left(A_{p}\right)$ and span $(\ell)$ determined, the maximum positive moment $\left(M_{\text {pos.tot } 1}\right)$ that the prestressing bars resists in simple support condition is given by the sum of the positive moments corresponding to the loads $g_{1}, g_{2}$, and $F_{1}$.

$$
\mathrm{M}_{\text {pos,tot, } 1}=\mathrm{M}_{1}+\mathrm{M}_{2}
$$

Table 2 presents the equations for the hypothetical flexural test for simply supported slabs.

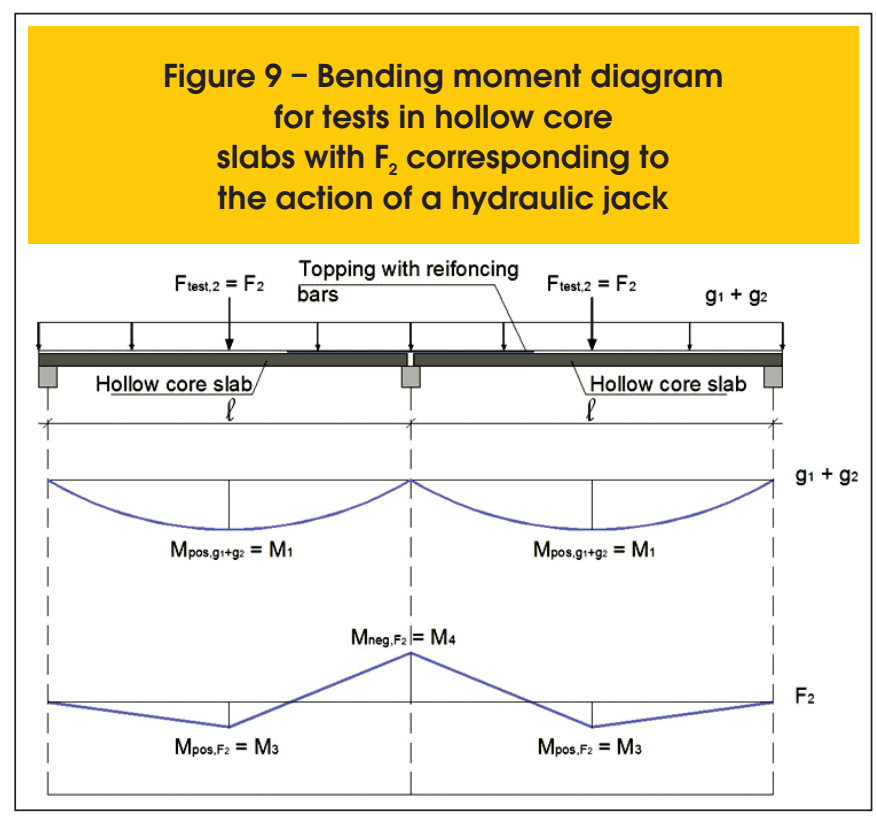

Figure 9 shows the bending moment diagram for the same slabs, assuming continuity in the intermediate support. In this Figure, $\mathrm{F}_{2}$ corresponds to the hydraulic jack in the continuity test. Thus, the total positive bending moment for this test $\left(M_{\text {pos,tot } 2}\right)$ is given by equation 2 .

$$
\mathrm{M}_{\text {pos,tot }, 2}=\mathrm{M}_{1}+\mathrm{M}_{3}
$$

$M_{\text {pos,tot }, 1}$ can be obtained using the value of $A_{p}$. The value of $M_{3}$, which corresponds to the positive moment due to the force $F_{2}$ applied to the middle of the slab for the test with continuity, can be obtained equating $M_{\text {pos,tot, } 1}$ with $M_{\text {pos,tot, } 2}$.

Once $M_{3}$ is known the $F_{2}$ force value can be calculated, and through this obtain the moment $M_{4}$. Finally, using $M_{4}$ the reinforcement bar, $A_{s}$, is calculated, in terms of $100 \%$ of continuity. After this the ratio between $F_{1}$ and $F_{2}$ can be determined. If $F_{2}$ is greater than $F_{1}$ it proves the increasing support capacity. Table 3 shows the equations to determine $A_{s}$ for the continuity tests.

In addition to the variables already determined, Table 3 also show:

- $z=$ lever arm balance in this section with simple bending. This value can be different, considering the balance with positive and negative moment;

- $\mathrm{f}_{\mathrm{yk}}=$ characteristic yielding stress of reinforcement bars.

\subsection{Bending moment $M_{4}$ and the support condition}

As the intermediate support consists of a connection in precast concrete, the value of $A_{s}$ is calculated with the negative bending moment $\left(\mathrm{M}_{4}\right)$ in the section in which rotation occurs. Thus the geometry of Figure 10 was used, according to the nomenclature shown below:

- $\mathrm{F}_{2}=$ concentrated load applied at the middle span for the test with continuity;

- $\theta=$ rotation in the section where the slab begins supporting on the beam (rotation section);

- $\mathrm{M}_{4,1}=$ negative bending moment at the center of the support;

- $\mathrm{M}_{4,2}=$ negative bending moment at the center of rotation; 


\section{Table 3 - Equations for calculating of hollow core slabs with continuity}

\begin{tabular}{|c|c|c|}
\hline Variable & Equation & Comments \\
\hline$M_{\text {pos, tot }, 2}$ & $\mathrm{M}_{\text {pos,tot }, 2}=\mathrm{M}_{\text {pos,tot }, 1}$ & See Equations land 2 \\
\hline$M_{3}$ & $\mathrm{M}_{3}=\mathrm{M}_{\text {pos,tot }, 2}-\mathrm{M}_{1}$ & See Figure 9 \\
\hline$F_{2}$ & $\mathrm{M}_{3}=\frac{5 . \mathrm{F}_{2} \cdot \mathrm{l}}{32} \Rightarrow \mathrm{F}_{2}=\frac{32 \cdot \mathrm{M}_{3}}{5 . \mathrm{l}}$ & See Figure 9 \\
\hline $\mathrm{M}_{4,1}$ & $\mathrm{M}_{4,1}=\frac{3 \cdot \mathrm{F}_{2} \cdot \mathrm{l}}{16}$ & See Figures 9 and 10 \\
\hline $\mathrm{M}_{4,2}$ & $M_{4,2}=M_{4,1}\left(\frac{\mathrm{l}_{1}}{\left(\mathrm{l}_{1}-\left(\mathrm{b}+\left(\begin{array}{l}\mathrm{a} \\
2\end{array}\right)\right)\right)}\right)$ & $\begin{array}{c}\text { See Equations } 3,4 \text { and } 5 \\
\text { See Figure } 10 .\end{array}$ \\
\hline$A_{s}$ & $A_{s}=\frac{M_{4,2}}{z \cdot f_{y k}}$ & $\begin{array}{l}\text { Area of reinforcement bars deduced by } \\
\text { balancing section for simple bending moment }\end{array}$ \\
\hline
\end{tabular}

- $\mathrm{M}_{3}=$ positive bending moment due to the $\mathrm{F}_{2}$;

a = distance between the edges of the hollow core slabs;

a $=$ support length of the hollow core slab;

- $\mathrm{c}=$ distance between the bending moment equal to zero and the rotation section;

- $\mathrm{h}_{\mathrm{c}}=$ height of the cover (topping);

- $\mathrm{h}_{\ell}=$ height of the hollow core slab;

- $\ell_{1}=$ distance between the fixed support and bending moment equal to zero;

- $\ell_{2}=$ distance between the concentrated load $\left(F_{2}\right)$ and the moment equal to zero;

- $\ell / 2=$ half of the span.

Figure 10 shows the relationships established in equations 3 and 4. Moreover, as a practical rule it is used for the length of the slab support (letter b in Figure 10) half of the height of the slab, for the composed section, see equation 5 .

$$
\mathrm{M}_{4,2}=\mathrm{M}_{4,1}\left\{\left[\ell_{1}-(\mathrm{b}+\mathrm{a} / 2)\right] /\left[\ell_{1}\right]\right\}
$$

$\ell_{1}=0,273 \ell$

$$
\mathrm{b}=\left(\mathrm{h}_{\mathrm{c}}+\mathrm{h}_{\ell}\right) / 2
$$

\subsection{Verification of the shear force}

The criteria suggested for establishing $100 \%$ of continuity reinforcement bars through the maximum moment of resistance by the prestressing bars must be complemented by verifying the shear force. Performing a continuity test (Figure 7) it can show that the hollow core slab reaches failure by shear force before the yielding or failure of the continuity reinforcement bar. In other words, the concentrated load corresponding to the failure can be less than that expected by the flexure analysis.

The verification of shear force in hollow core slabs is widely researched. A recent study by CATOIA [11] addresses this verification in regions of flexural cracks. In Catoia's work, several shear

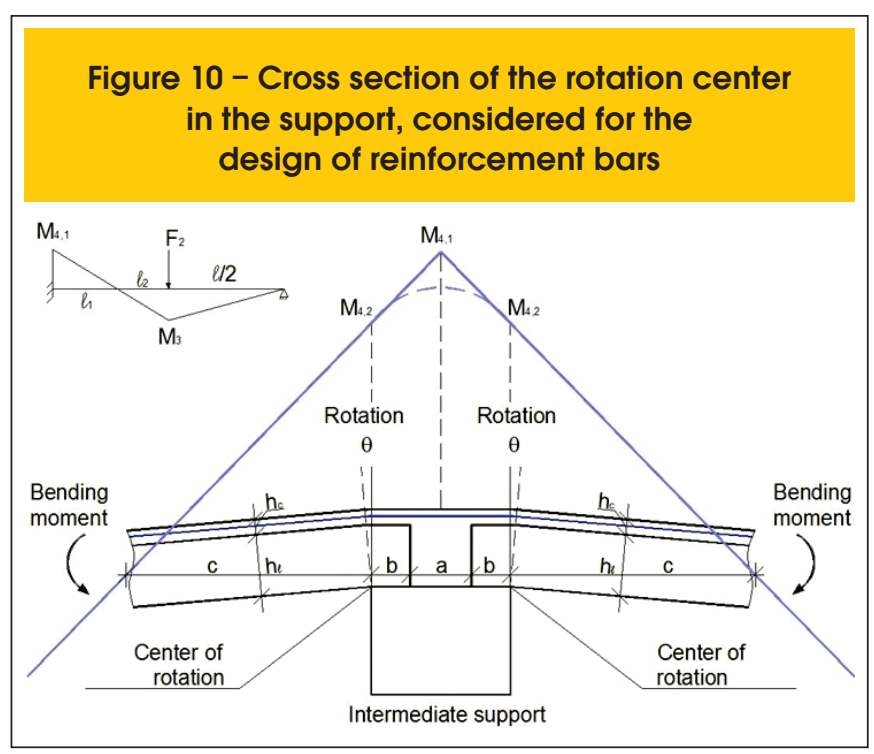


Table 4 - Equations for calculating of hollow core slabs with continuity - verification of shear force

\begin{tabular}{|c|c|c|}
\hline Variable & Equation & Comments \\
\hline $\mathrm{F}_{2, Q}$ & $\frac{\left(g_{1}+g_{2}\right) \cdot l}{2}+\frac{11}{16} \cdot F_{2, Q}=\left[\tau_{R d} \cdot k\left(1,2+40 \cdot \rho_{1}\right)+0,15 \sigma_{c p}\right] \cdot b_{w} \cdot d$ & See expressions 6 and 7 \\
\hline$F_{2} \geq F_{2, Q}$ & $\begin{array}{l}\text { OK. } A_{s} \text { is equal to the value obtained in Table } 3 \text {. } \\
\text { The slab does not undergo failure by shear force. }\end{array}$ & See Table 3 \\
\hline $\mathrm{F}_{2}<\mathrm{F}_{2, Q}$ & $\begin{array}{l}M_{4,1}, M_{4,2} \text { and } A_{s} \text { is calculated again, } \\
\text { replacing } F_{2} \text { by } F_{2, Q} \text { in Table } 3 .\end{array}$ & See Table 3 \\
\hline
\end{tabular}

force equations were studied and compared with test results. The equation of the Brazilian code ABNT NBR 6118:2007 [12] was satisfactory evaluated in terms of verifying shear force, especially for hollow core slabs with or without topping and concentrated load applied at $2.5 \mathrm{~h}$, where $\mathrm{h}$ is the height of the element being tested (section with or without topping).

The shear force was verified using the formulation of the Brazilian code ABNT NBR 6118:2007 [12] which is based on the European formulation, and which serves as a basis for its use in another Brazilian code, ABNT NBR 14861:2011 [13] that especially addresses the hollow core slabs. However, they are similar especially when there is no filled cores, as in this work.

According to Brazilian code ABNT NBR 6118:2007 [12], a slab can be made without transverse tension reinforcement when the equation 6 is satisfied.

\section{Figure 11 - Flow chart of the calculation of $A_{s}$ by the criteria suggested for the maximum $r$ esistance moment of the hollow core slab}

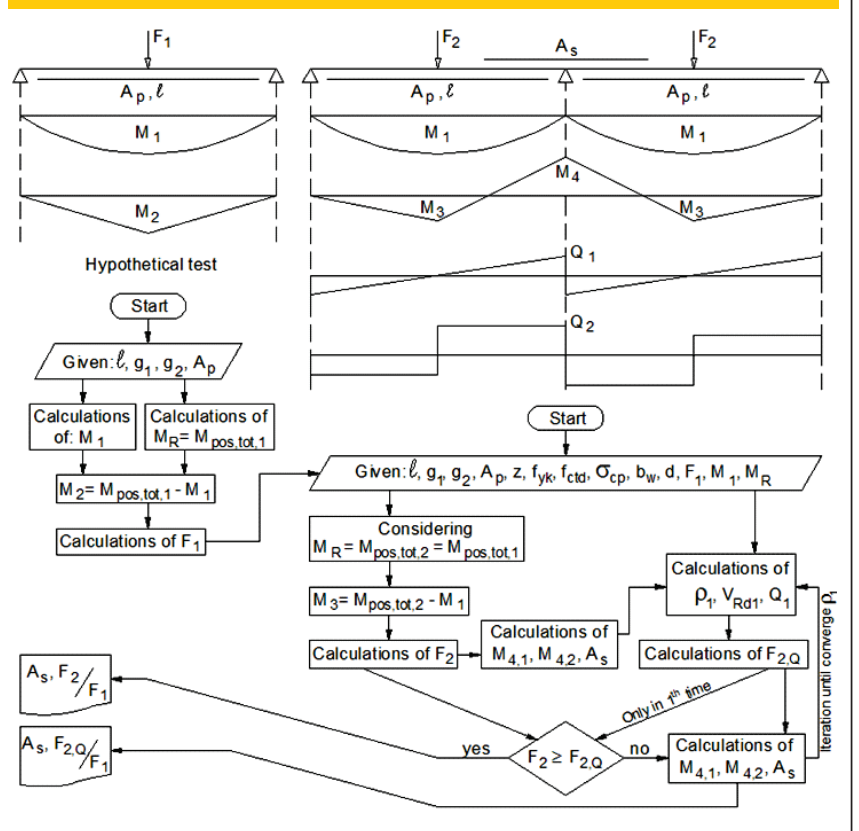

$$
\mathrm{V}_{\mathrm{Sd}} \leq \mathrm{V}_{\mathrm{Rd} 1}=\left[\tau_{\mathrm{Rd}} \mathrm{k}\left(1,2+40 \rho_{1}\right)+0.15 \sigma_{\mathrm{cp}}\right] \mathrm{b}_{\mathrm{w}} \mathrm{d}
$$

- $V_{S d}=$ acting shear force of design;

- $\mathrm{V}_{\mathrm{Rd} 1}=$ resisting shear force of design;

- $\tau_{\mathrm{Rd}}=$ resisting shear stress of design $-\mathrm{T}_{\mathrm{Rd}}=0,25 \mathrm{f}_{\mathrm{ctd}}$;

- $\mathrm{f}_{\text {ctd }}=$ concrete tensile strength $-\mathrm{f}_{\text {ctd }}=\mathrm{f}_{\text {ctk,inf }} / \mathrm{Y}_{\mathrm{c}}$;

- $\mathrm{k}=|1.6-\mathrm{d}| \geq 1$ ( $\mathrm{d}$ in meters);

- $\rho_{1}=A_{s 1} /\left(b_{w} d\right) \leq 0.02$;

- $A_{s 1}=$ steel area considered in the pin effect;

- $\mathrm{b}_{\mathrm{w}}=$ slab width discounting voids corresponding to the cores;

- $d=$ depth of the slab, measured from the extreme compression fiber to the centroid of the tensioning reinforcement;

- $\sigma_{\mathrm{cp}}=$ concrete compression stress due to the prestressing force $-\sigma_{\mathrm{cp}}=\mathrm{N}_{\mathrm{sd}} / \mathrm{A}_{\mathrm{c}}$;

- $\mathrm{N}_{\mathrm{Sd}}=$ longitudinal force due to prestressing;

- $\mathrm{A}_{\mathrm{c}}=$ area of the concrete cross section.

Equation 7 shows the $V_{S d}$ value considering the concentrated load applied to the continuity test responsible for the failure by shear $\left(F_{2, Q}\right)$. This equation considers that the concentrated load $\left(F_{2}\right)$ is applied in the middle of the span, as shown in Figure 9. If there is any change in the position of the concentrated load, equation 7 should be adapted.

$$
\mathrm{V}_{\mathrm{Sd}}=\left(\mathrm{g}_{1}+\mathrm{g}_{2}\right) \cdot(\ell / 2)+(11 / 16) \mathrm{F}_{2, \mathrm{Q}}
$$

Therefore, the force value one wants to know $\left(F_{2, Q}\right)$ depends on the reinforcement ratio $\left(\rho_{1}\right)$, in other words, $F_{2, Q}$ depends on the negative reinforcement $\left(A_{s}\right)$.

Therefore the $A_{s}$ value is used to verify shear, with $A_{s}$ obtained according to the flexural test with continuity, and then the $\mathrm{F}_{2, \mathrm{Q}}$ is calculated. If $F_{2}$ is less than $F_{2, Q}$, the slab will not achieve failure by shear force. Otherwise, the continuity reinforcement will have to be calculated again, limited by the force $F_{2, Q}$. This can be done by replacing, in Table $3, F_{2}$ by $F_{2, Q}$, again calculating $M_{4,1}$ and $M_{4,2}$, and finally $A_{s}$. Table 4 shows the summary of the equations when shear force is considered. Figure 11 presents the flow chart of the calculation of 
Figure 12 - Hollow core slabs used in the test and manufactured by LATTICE SLAB (LAJE TRELIÇADA) IND. and COM. LTDA

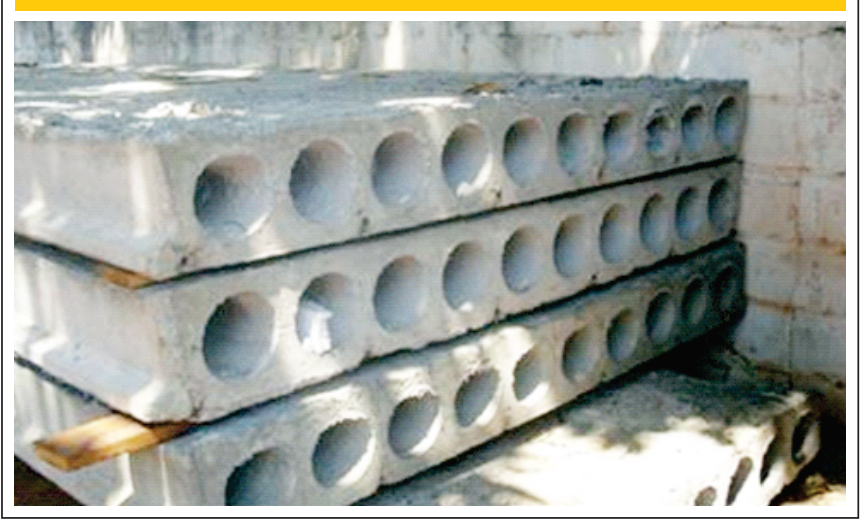

$A_{s}$ by the criteria suggested to establish $100 \%$ of continuity reinforcement bars for the maximum resistance moment of the hollow core slab.

\section{Experimental program}

The experimental test in this paper is part of an ongoing doctoral program at the Department of Structural Engineering, Sao Carlos School of Engineering, University of Sao Paulo (SET/EESC/ USP), in Brazil. The tests are being conducted at the Study and Technology Center in Precast Concrete, Department of Civil Engineering, Federal University of Sao Carlos (NETPRE/DECiv/ UFSCar). The hollow core slabs were donated to this research as part of the agreement between the Brazilian Association of Industrialized Concrete Construction $(A B C / C)$ and the aforementioned universities. The slabs were manufactured by LATTICE SLAB (LAJE TRELIÇADA) IND. and COM. LTDA., head- quartered in Cuiaba (MT), and comprise a part of the hollow core slabs (Figure 12) for the soccer stadium Arena Pantanal, in Cuiaba, Mato Grosso state, Brazil.

The experimental test in question was performed on March 7, 2012 in full-scale hollow core slabs. These slabs had the following dimensions: width $2.00 \mathrm{~m}$, length $6.00 \mathrm{~m}$ and height $0.21 \mathrm{~m}$. Figure 13 shows a panoramic view of the test.

Figure 14 shows the cross section of the hollow core slab. For the concrete compressive characteristic strength $\left(f_{c k}\right)$ and the concrete compressive strength at 24 hours $\left(f_{c i, 24 h}\right) 40 \mathrm{MPa}$ and $21 \mathrm{MPa}$ were used, respectively. For the prestressing bars, 9-wire strands of $12.7 \mathrm{~mm}$ diameter, steel CP 190 - RB were used. The initial prestressing force (in each strand) was $142 \mathrm{kN}$. The geometric properties are shown in Table 5, while the material properties are shown in Table 6.

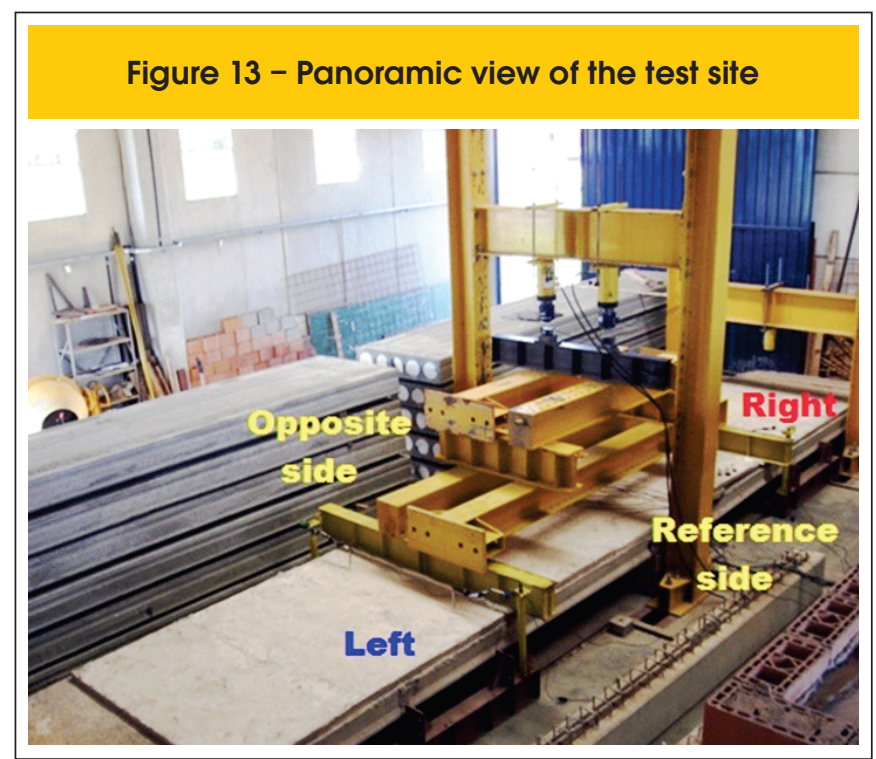

Table 5 - Geometric properties

\begin{tabular}{|c|c|c|c|}
\hline Meaning & Variables & Simple section & Composed section \\
\hline Steel area of prestressing bars & $A_{p}\left(\mathrm{~cm}^{2}\right)$ & 8.91 & 8.91 \\
\hline $\begin{array}{l}\text { Distance between the prestressing bars and } \\
\text { extreme bottom fiber of slab }\end{array}$ & $d^{\prime}(m)$ & 0.035 & 0.035 \\
\hline Area of the concrete cross section & $A_{c}\left(m^{2}\right)$ & 0.2357 & 0.3342 \\
\hline Moment of inertia & $\mathrm{I}\left(\mathrm{m}_{4}\right)$ & 0.0013 & 0.0024 \\
\hline $\begin{array}{c}\text { Distance between the upper fiber and the } \\
\text { neutral axis (LN) }\end{array}$ & $\mathrm{y}_{\mathrm{s}}(\mathrm{m})$ & 0.1016 & 0.1143 \\
\hline $\begin{array}{c}\text { Distance between the bottom fiber and the } \\
\text { neutral axis (LN) }\end{array}$ & $y_{i}(m)$ & 0.1084 & 0.1457 \\
\hline Modulus of strength above neutral axis & $W_{s}\left(m^{3}\right)$ & 0.0128 & 0.0210 \\
\hline Modulus of strength below neutral axis & $W_{i}\left(m^{3}\right)$ & 0.01199 & 0.01647 \\
\hline $\begin{array}{c}\text { Eccentricity of prestressing bars (distance } \\
\text { between the center of prestressing bars and } \\
\text { the neutral axis) }\end{array}$ & $e_{p}(m)$ & 0.0734 & 0.1107 \\
\hline
\end{tabular}


Differently from Figures 8 and 9 , the concentrated load was applied at a distance of $2.10 \mathrm{~m}$ from the center of the model, as shown in Figure 15. The span $(\ell)$ of the test was $4.82 \mathrm{~m}$.

\section{Results}

Using the methodology set out in item 4 of this paper, it is possible to draw curves simulating other tests for the slab in question. Table 7 shows the design of the continuity reinforcement bars for the followings spans (in meters): $3.75 ; 5.00 ; 6.25 ; 7.50 ; 8.75 ; 10.00$.

Table 8 shows the summary of the concentrated loads for the failure, also indicating the real capacity increase of the slab to withstand the loads, through the $F_{2} / F_{1}$ ratio and the shear force resistance $\left(F_{1, Q}\right)$ for the simple support test.

Based on Table 8 it was possible to plot the curves shown in Figure 16. This figure shows five curves relating the concentrated load to the failure of the slab, by flexure $\left(F_{1}\right.$ or $\left.F_{2}\right)$ or shear $\left(F_{1, Q}\right.$ or $\left.F_{2, Q}\right)$ with the spans for the hypothetical tests in Table 7.

These curves are explained below. In all cases, it is considered that the forces are positioned at the middle span of each slab.

- $F_{1}$ - Simple supports - Flexural - Concentrated loads of the hypothetical simple supports slabs in flexural tests;
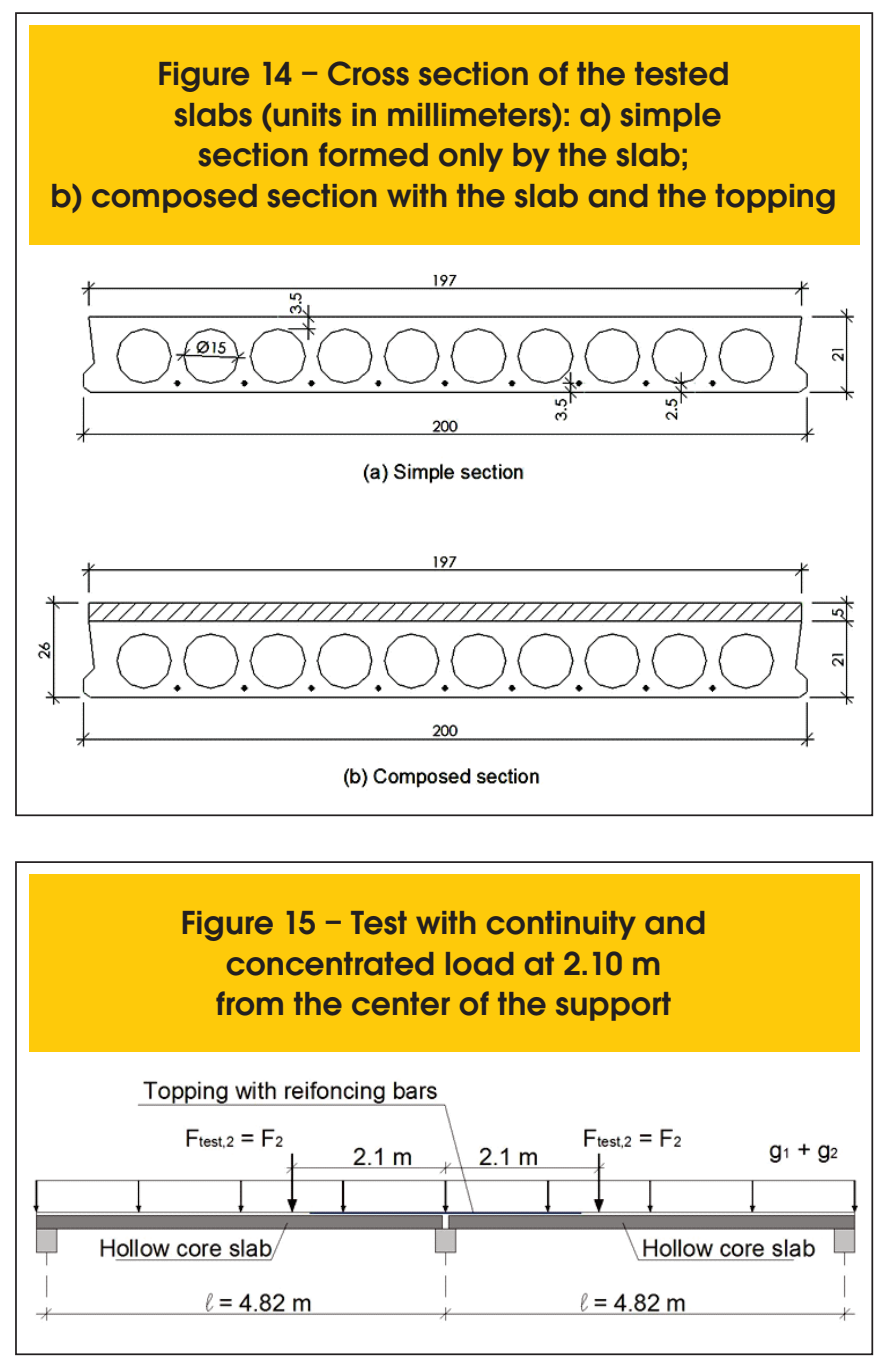

\begin{tabular}{|ccc|}
\hline \multicolumn{3}{|c|}{ Table 6 - Material properties } \\
\hline Material & Variables & Values \\
& & \\
Concrete & $\mathrm{f}_{\mathrm{ck}}(\mathrm{MPa})$ & 30 \\
of topping & $\mathrm{E}_{\mathrm{ci,cml}}(\mathrm{MPa})$ & 30672 \\
Concrete & $\mathrm{f}_{\mathrm{ck}}(\mathrm{MPa})$ & 40 \\
of slabs & $\mathrm{E}_{\mathrm{cl}, \mathrm{cpm}}(\mathrm{MPa})$ & 35418 \\
Negative & $\mathrm{f}_{\mathrm{yk}}(\mathrm{MPa})$ & 500 \\
reinforcement & $\mathrm{E}_{\mathrm{s}}(\mathrm{MPa})$ & 210000 \\
bars & $\varepsilon_{\mathrm{yd}}(\%)$ & 2.07 \\
(CA-50) & $\mathrm{f}_{\mathrm{ptk}}(\mathrm{MPa})$ & 1900 \\
Prestressing & $\mathrm{f}_{\mathrm{pyk}}(\mathrm{MPa})$ & 1710 \\
reinforcement & $\mathrm{E}_{\mathrm{p}}(\mathrm{MPa})$ & 205000 \\
bars & $\varepsilon_{\mathrm{yd}}(\%)$ & 8.53 \\
(CP 190 RB) & & \\
\hline
\end{tabular}

- $\mathrm{F}_{1, \mathrm{Q}}$ - Simple supports - Shear - Concentrated loads of the hypothetical simple supports slabs in shear tests;

- $\mathrm{F}_{2}$ - Continuity - Flexural - Concentrated loads corresponding to the hypothetical slabs with continuity in flexural tests;

- $\mathrm{F}_{2, \mathrm{Q}}$ - Continuity - Shear - Concentrated loads corresponding to the hypothetical slabs with continuity in shear tests;

- $\mathrm{F}_{2, \mathrm{E}}$ - Continuity - Envelopment - Considers the most unfavorable situation between $\mathrm{F}_{2}$ and $\mathrm{F}_{2, \mathrm{Q}}$ characterizing an envelope. This envelope can also be seen in Tables 7 and 8, emphasizing the most unfavorable situation.

\subsection{Calculation of the continuity reinforcement bars to use in the tests}

The calculations to obtain the continuity reinforcement bars $\left(A_{s}\right)$ for the tests are presented.

Figure 15 shows the configuration of the span $(\ell)$ and the position of the applied load $\left(F_{2}\right)$. This test used a span of $4.82 \mathrm{~m}$, and the distance from the center of the model to the load application point of $2.10 \mathrm{~m}$. Therefore, it should be mentioned that the internal stress was calculated in accordance with the test configuration. This was performed by using the conversions shown in Table 9.

Moreover, the following should be taken into account:

- $\sigma_{\mathrm{pt}, \infty}=107.67 \mathrm{kN} / \mathrm{cm}^{2}$ (prestressing stress considering the losses, calculated from manufacturing until the date of the test, equals to $24.18 \%$ );

- $\mathrm{N}_{\mathrm{p}}=107.67\left(\mathrm{kN} / \mathrm{cm}^{2}\right) \times 8.91\left(\mathrm{~cm}^{2}\right)=959.29 \mathrm{kN}$ (prestressing force acting on the section).

The results are shown in Tables 10,11,12 and 13. Note that as it is an experimental analysis $f_{c k}$ was used instead of $f_{c d}$. The same applies to the value of $f_{\text {ctd }}$, which was replaced by $f_{\text {ctkinf }}$.

Since the value of $F_{2, Q}$ is less than that of $F_{2}$, it is necessary repeat the calculations in Table 11 using $F_{2, Q}$ instead of $F_{2}$, and this is done in Table 13.

It is worth noting that the increasing load capacity of the slab was of 1.09 (Table 12) and not 1.82 (Table 10). 
Table 7 - Simulation of tests for spans between $3.75 \mathrm{~m}$ and $10.00 \mathrm{~m}$

\begin{tabular}{|c|c|c|c|c|c|c|}
\hline$\ell(m)$ & 3.75 & 5.00 & 6.25 & 7.50 & 8.75 & 10.00 \\
\hline$M_{1}(k N . m)$ & 14.75 & 26.22 & 40.97 & 58.99 & 80.29 & 104.88 \\
\hline $\mathrm{M}_{2}$ (kN.m) & 312.69 & 301.22 & 286.47 & 268.45 & 247.15 & 222.57 \\
\hline $\mathrm{F}_{1}(\mathrm{kN})$ & 333.54 & 240.98 & 183.34 & 143.17 & 112.98 & 89.03 \\
\hline $\mathrm{M}_{3}(\mathrm{kN} . \mathrm{m})$ & 312.69 & 301.22 & 286.47 & 268.45 & 247.15 & 222.57 \\
\hline $\mathrm{F}_{2}(\mathrm{kN})$ & 533.66 & 385.56 & 293.35 & 229.08 & 180.77 & 142.44 \\
\hline $\mathrm{F}_{2} / \mathrm{Fl}$ & 1.60 & 1.60 & 1.60 & 1.60 & 1.60 & 1.60 \\
\hline $\mathrm{M}_{4,1}(\mathrm{kN} \cdot \mathrm{m})$ & 375.23 & 361.47 & 343.77 & 322.14 & 296.57 & 267.08 \\
\hline$\ell_{1}(\mathrm{~m})$ & 1.024 & 1.365 & 1.706 & 2.048 & 2.389 & 2.730 \\
\hline $\mathrm{M}_{4,2}(\mathrm{kN} . \mathrm{m})$ & 301.93 & 308.50 & 303.47 & 290.67 & 271.74 & 247.51 \\
\hline$A_{s}\left(\mathrm{~cm}^{2}\right)$ & 28.16 & 28.77 & 28.30 & 27.04 & 25.22 & 22.87 \\
\hline$\rho_{1}$ (calculated) & 0.02537 & 0.02576 & 0.02511 & 0.02375 & 0.02182 & 0.01939 \\
\hline$\rho_{1}$ (adopted) & $0.01433^{\star}$ & 0.02 & 0.02 & 0.02 & 0.02 & 0.02 \\
\hline $\mathrm{V}_{\mathrm{Rd} 1}(\mathrm{kN})$ & 208.64 & 227.60 & 227.60 & 227.60 & 227.60 & 227.60 \\
\hline $\mathrm{F}_{2, \mathrm{Q}}(\mathrm{kN})$ & 280.60 & 300.55 & 292.92 & 285.29 & 277.67 & 270.04 \\
\hline $\mathrm{F}_{2, \mathrm{Q}} / \mathrm{F}_{1}$ & 0.84 & 1.25 & 1.59 & 1.99 & 2.46 & 3.03 \\
\hline $\mathrm{F}_{2}$ (adopted) & 280.60 & 300.55 & 292.93 & 229.08 & 180.08 & 142.44 \\
\hline $\mathrm{F}_{2} / \mathrm{F}_{1}$ (real) & 0.84 & 1.25 & 1.59 & 1.60 & 1.60 & 1.60 \\
\hline $\mathrm{M}_{4,1}(\mathrm{kN} \cdot \mathrm{m})$ & 197.30 & 281.76 & 343.27 & 322.14 & 296.57 & 267.08 \\
\hline $\mathrm{M}_{4,2}$ (kN.m) & 158.75 & 240.48 & 303.03 & 290.67 & 271.74 & 247.51 \\
\hline$A_{s}\left(\mathrm{~cm}^{2}\right)$ & 14.50 & 22.17 & 28.26 & 27.04 & 25.22 & 22.81 \\
\hline$\rho_{1}($ calculated $)$ & $0.01433^{*}$ & 0.02190 & 0.02792 & 0.02672 & 0.02492 & 0.02254 \\
\hline$A_{p}\left(\mathrm{~cm}^{2}\right)$ & 8.91 & 8.91 & 8.91 & 8.91 & 8.91 & 8.91 \\
\hline$\rho_{1}($ calculated) & 0.008804 & 0.008804 & 0.008804 & 0.008804 & 0.008804 & 0.008804 \\
\hline $\mathrm{V}_{\mathrm{Rd1}, \mathrm{FIQ}}(\mathrm{kN})$ & 190.17 & 190.17 & 190.17 & 190.17 & 190.17 & 190.17 \\
\hline $\mathrm{F}_{1, Q}(\mathrm{kN})$ & 348.878 & 338.39 & 327.42 & 317.42 & 306.93 & 296.44 \\
\hline
\end{tabular}

Table 8 - Summary of the concentrated loads in terms of failure

\begin{tabular}{|c|c|c|c|c|c|c|}
\hline$l(m)$ & $F_{1}(k N)$ & $\mathbf{F}_{1, Q}(\mathbf{k N})$ & $\mathrm{F}_{2}(\mathbf{k N})$ & $\mathbf{F}_{2, Q}(\mathbf{k N})$ & $\mathbf{F}_{2, \mathrm{E}}(\mathbf{k N})$ & $\mathbf{F}_{2} / \mathbf{F}_{1}$ \\
\hline 3.75 & 333.54 & 348.88 & 533.66 & 280.60 & 280.60 & 0.84 \\
\hline 5.00 & 240.98 & 338.39 & 385.56 & 300.55 & 300.55 & 1.25 \\
\hline 6.25 & 183.34 & 327.90 & 293.35 & 292.92 & 292.92 & 1.59 \\
\hline 7.50 & 143.17 & 317.42 & 229.08 & 285.29 & 229.08 & 1.60 \\
\hline 8.75 & 112.98 & 306.93 & 180.77 & 277.67 & 180.77 & 1.60 \\
\hline 10.00 & 89.03 & 296.44 & 142.44 & 270.04 & 142.44 & 1.60 \\
\hline
\end{tabular}


Thus, the continuity reinforcement bars corresponding to $100 \%$ is $A_{s}=19.56 \mathrm{~cm}^{2}$, limited by the verification of the shear force. Therefore, 17 bars of diameter $12.5 \mathrm{~mm}$ were used, spaced of $12 \mathrm{~cm}$, totaling $20.86 \mathrm{~cm}^{2}$.

The cracking moment of the topping $\left(\mathrm{M}_{\mathrm{r}}\right)$ and the force $\mathrm{F}_{2}$ corresponding to this cracking are shown and calculated in Table 14.

\subsection{Test results}

Figure 17 shows the force-displacement curves $\left(F_{2}\right.$ versus $\left.\delta\right)$ obtained from the values measured by the load cells and displacement transducers. The blue curve (right in Figure 17) and the red curve (left) correspond to the slabs highlighted in blue (left of Figure 17) and red (right). In addition, the $F_{2}$ value includes the selfweight of the rigid steel beams (equal to $10.7 \mathrm{kN}$ ) and the force applied by the hydraulic jack.

The maximum load obtained, also considering the self-weight value of the rigid steel beams, was $F_{2}=272.0 \mathrm{kN}$ (each slab).

The cracking moment of the topping can be seen in the curves of Figure 17 for values of around $F_{2}=107.9 \mathrm{kN}$.

Moreover, based on Figure 17, the maximum displacements resulted in $\delta=4.7 \mathrm{~mm}$ and $\delta=9.5 \mathrm{~mm}$, respectively, at the right (in

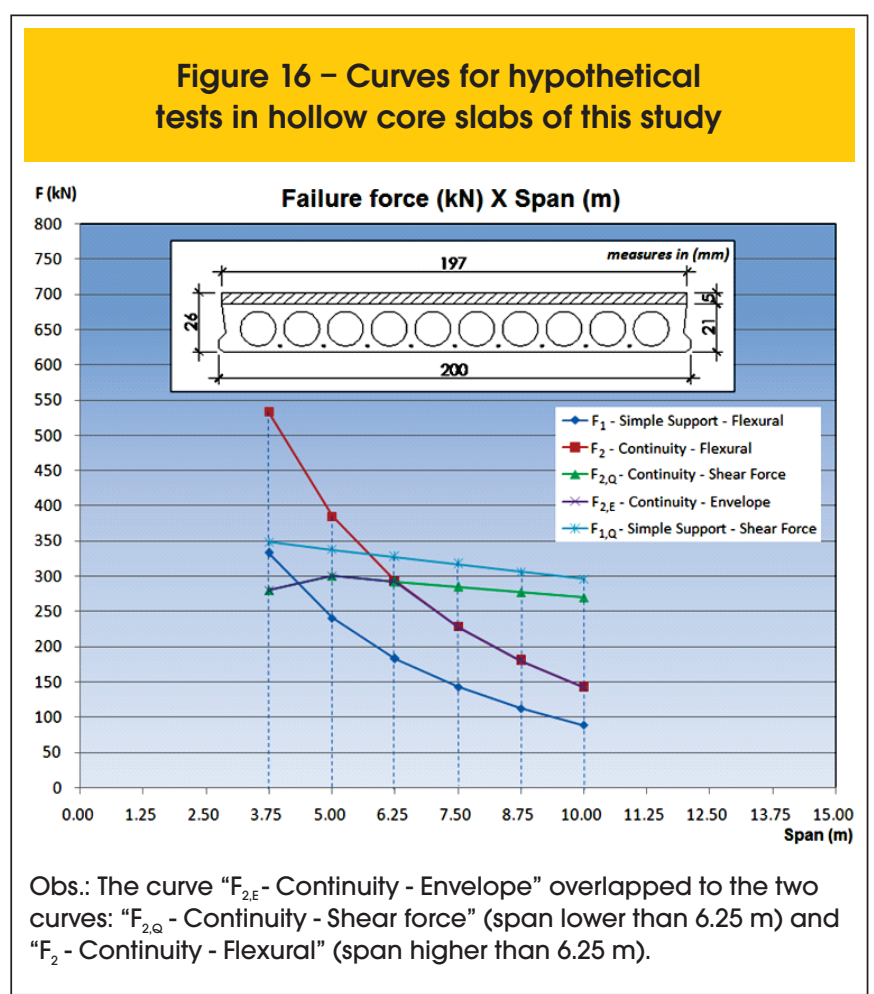

\begin{tabular}{|ccc|}
\hline $\begin{array}{c}\text { Table 9 - Relations between the internal } \\
\text { forces and the applied load }\end{array}$ \\
$\mathrm{M}_{4,1}$ & $\mathrm{M}_{3}$ & $Q$ \\
$\mathrm{k}_{1} \cdot \mathrm{F}_{2} \cdot l$ & $\mathrm{k}_{2} \cdot \mathrm{F}_{2} \cdot l$ & $\mathrm{k}_{3} \cdot \mathrm{F}_{2}$ \\
$\mathrm{k}_{1}=0.192324$ & $\mathrm{k}_{2}=0.137344$ & $\mathrm{k}_{3}=0.7565$ \\
\hline
\end{tabular}

red, Figure 13) and left (in blue, in the same figure).

\section{Conclusions}

According to the results it is concluded that the method presented was able to accurately predict the behavior of the system and especially the failure mode, showing to be adequate for planning continuity tests in hollow core slabs subjected to concentrated loads. The following facts were observed:

- The model tested reached failure by shear force, as provided in the calculations;

- The $F_{2}$ force estimated for the cracking of the topping $\left(F_{2}=117.59 \mathrm{kN}\right.$, Table 14) was close to the real condition $\left(F_{2}=107.9 \mathrm{kN}\right.$, Figure 17);

- Similarly, the $F_{2}$ force estimated for the shear failure $\left(F_{2}=274.13 \mathrm{kN}\right.$, Table 12) was very close to the value achieved in the test $\left(F_{2}=272.0 \mathrm{kN}\right.$, Figure 17).

Table 10 - Calculations to obtain the concentrated load corresponding to the failure $\left(F_{2}\right)$ in the continuity test

$$
\mathrm{M}_{\text {pos,tot, } 1}
$$

Calculated by balancing section for simple flexure. It is inverse calculation using $A_{p}$ of the hollow core slab.

$\mathrm{M}_{\text {pos,tot }, 1}=327.44 \mathrm{kN} . \mathrm{m}$

\section{$\mathbf{M}_{1}$}

$\mathrm{M}_{1}=\frac{\left(\mathrm{g}_{1}+\mathrm{g}_{2}\right) \mathrm{l}^{2}}{8}=\frac{(5.89+2.5) 4.82^{2}}{8}=24.36 \mathrm{kN} . \mathrm{m}$

$\mathrm{M}_{2}$

$\mathrm{M}_{2}=\mathrm{M}_{\text {pos,tot, } 1}-\mathrm{M}_{1}=327.44-24.32=303.12 \mathrm{kN} . \mathrm{m}$

$$
\mathrm{F}_{1}=\frac{4 \mathrm{M}_{2}}{\mathrm{l}}=\frac{4 \times 303.12}{4.82}=251.55 \mathrm{kN}
$$

$\mathrm{M}_{\text {pos,tot }, 2}=\mathrm{M}_{\text {pos,tot } 1}$
$\mathrm{M}_{3}=\mathrm{M}_{\text {pos,tot, } 2}-\mathrm{M}_{1}=327.44-24.32=303.12 \mathrm{kN} \cdot \mathrm{m}$
$\mathrm{F}_{2}=\frac{\mathrm{F}_{2}}{\mathrm{k}_{2} \times \mathrm{l}}=\frac{303.12}{0.137344 \times 4.82}=457.89 \mathrm{kN}$
$\frac{\mathrm{F}_{2}}{\mathrm{~F}_{1}}=\frac{457.89}{251.55}=1.82$


Figure 17 - Force-displacement curves (red on the left, concerning to the right side of the slab)

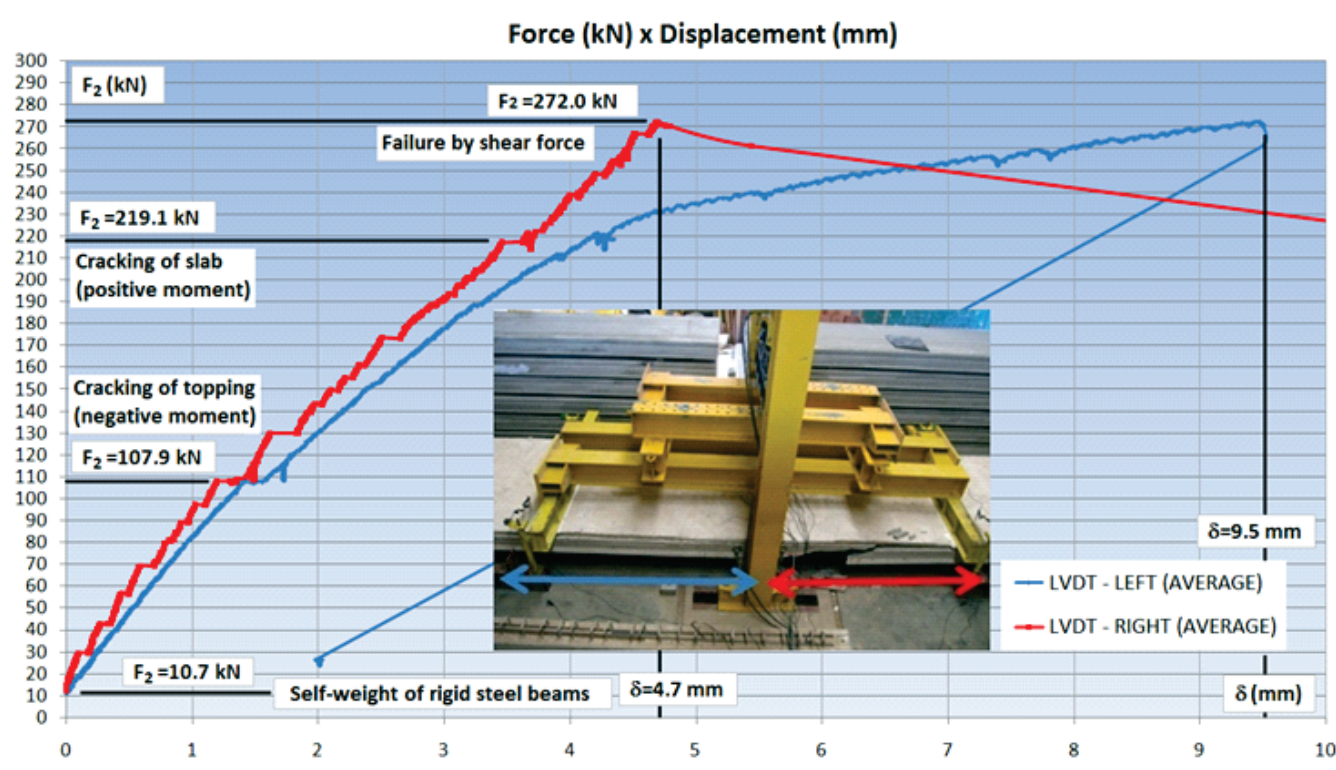

With regard to the curves shown in Figure 16 it is observed that the relationship between the forces corresponding to the flexural failure with continuity and the simple support slabs, $F_{2} / F_{1}$, is always equal to 1.6 (see Table 7). This relationship can be visually verified in Figure 16. If only the flexural failure results were considered, it could be conclude for all cases that continuity increases by 1.6 times the resistance of hollow core slabs. However this conclusion is only possible for the slabs with span equal to $6.25 \mathrm{~m}$ or above. There is also a relationship between the forces corresponding to the failure by shear forces $\left(F_{1, Q}\right.$ and $\left.F_{2, Q}\right)$. This relationship is affected by the rate of continuity reinforcement $\left(\rho_{1}\right)$ adopted for each situation. However, taking into account only the results of shear

Table 11 - Calculations of continuity reinforcement bars (As) considering flexure

$\mathrm{M}_{4,1}=\mathrm{k}_{1} \times \mathrm{F}_{2} \times \mathrm{l}=0.192324 \times 457.89 \times 4.82=424.46 \mathrm{kN} . \mathrm{m}$
$\mathrm{b}=\frac{\mathrm{h}_{\mathrm{c}}+\mathrm{h}_{1}}{2}=\frac{0.05+0.21}{2}=0.13 \mathrm{~m}$
$\mathrm{l}_{1}=1.225 \mathrm{~m}$
$\mathrm{M}_{4,2}=\mathrm{M}_{4,1}\left(\frac{\left.\mathrm{M}_{1,2}-\left(\mathrm{b}+\left(\frac{\mathrm{a}}{2}\right)\right)\right)}{\mathrm{l}_{1}}\right)=424.46\left(\frac{1.225-(0.13+0.07)}{1.225}\right)=355.16 \mathrm{kN} . \mathrm{m}$
$\mathrm{A}_{\mathrm{s}}=\frac{\mathrm{M}_{4,2}}{\mathrm{z}_{\mathrm{s}} . \mathrm{f}_{\mathrm{yk}}}=\frac{355.16 \quad \mathrm{~A}_{\mathrm{s}}}{0.212 \times 500000}=0.003351 \mathrm{~m}^{2}=33.51 \mathrm{~cm}^{2}$


Table 12 - Verifying shear force and obtaining the force $F_{2, Q}$

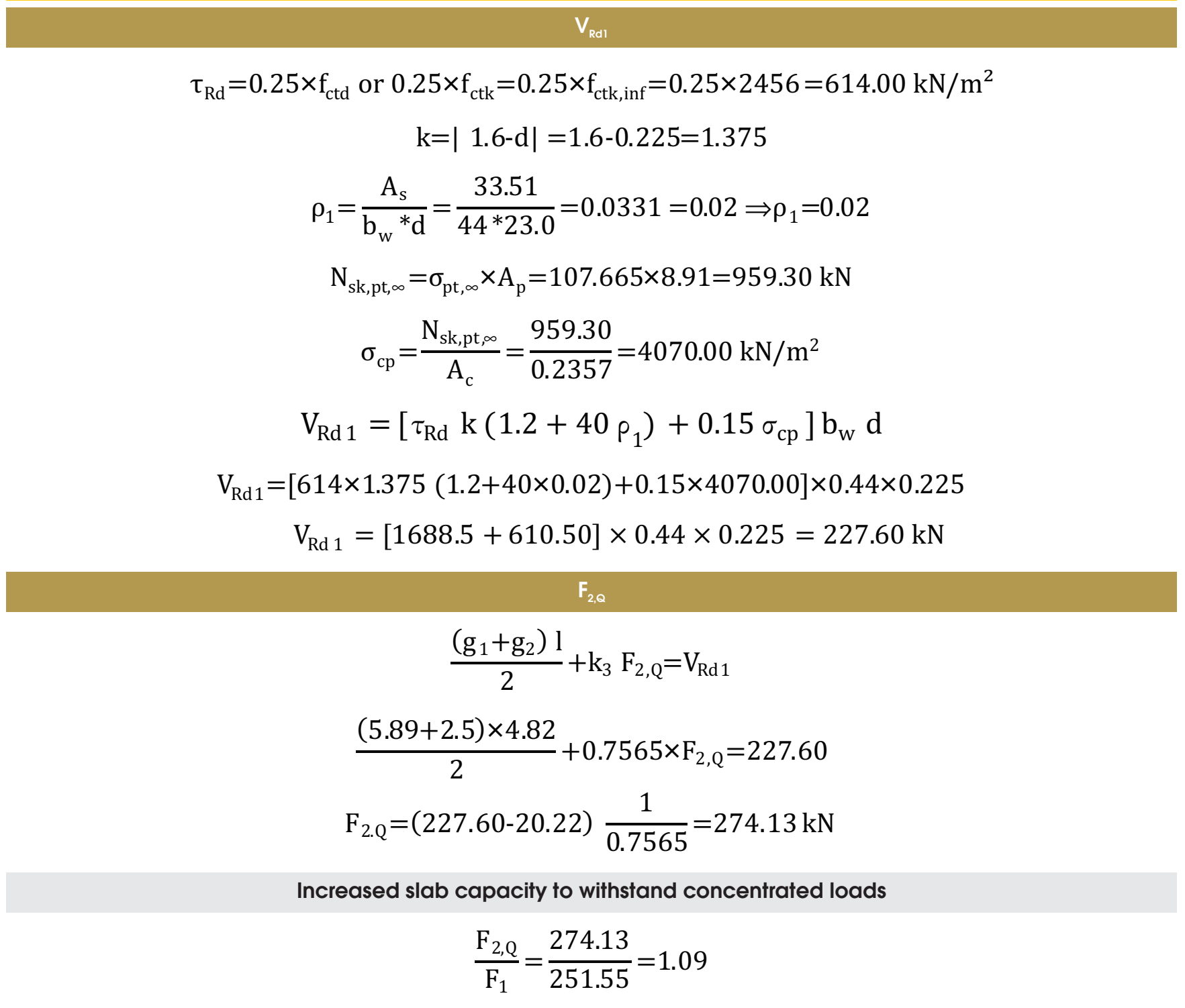

forces, it is concluded that the shear strength decreases when continuity is promotes. This fact was expected given that in the simple support condition the shear force is equivalent to the half of the force $F_{1, Q}$, while in the continuity condition, the support considered absorbs more load, with this ratio equal to $(11 / 16) F_{2 Q}$. For the cases with continuity at the two supports, the curve of $F_{1, Q}$ is equal to that of $F_{2, Q}$. This is because even with continuity the shear force is equivalent to half of the applied force.

The curve " $F_{2, E}$ - Continuity - Envelope" represents the envelope of the slab with continuity considering the failure by flexure or shear force. Analyzing the two effects simultaneously (flexural or shear) it is concluded that the failure mode would be by shear force for the followings spans $\ell=3.75 \mathrm{~m} ; \ell=5.00 \mathrm{~m}$ and $\ell=6.25 \mathrm{~m}$. For the first case $(\ell=3.75 \mathrm{~m})$ there is no load resistance increase in the slabs, that is, the failure force value for the flexure tests with continuity
$\left(F_{2}\right)$ is lower than the failure force value of the simple support tests $\left(F_{1}\right)$. For the last cases $(\ell=7.50 \mathrm{~m} ; \ell=8.75 \mathrm{~m}$ and $\ell=10.00 \mathrm{~m})$, the failure occurs by flexure.

When analyzing the efficiency of continuity $\left(\mathrm{F}_{2} / \mathrm{F}_{1}\right.$, last column of Table 8 ), the slabs that performed better were those limited by flexural failure. Furthermore, Figure 16 shows the efficiency of the continuity condition by the distance between the curve $F_{2 E}$ and those below this: the curve $F_{2, Q}$ for the span of $3.75 \mathrm{~m}$ (inefficient) and the curve $F_{1}$ for the other slabs.

As the focus of this study is not to analyze the cases with filling cores, this is not depicted in Figure 16. However, when this fact is taken into consideration, the tendency is that the shear force values increase. In other words, in Figure 16, the curve $F_{2, Q}$ would move upward, further improving the continuity efficiency $\left(F_{2} / F_{1}\right)$ in the first envelope section. 


\section{Table 13 - Calculation of the continuity reinforcement bars (As) for flexural, limited by verification of shear force}

\section{$\mathrm{M}_{4, \mathrm{I}}$}

$$
\mathrm{M}_{4,1}=\mathrm{k}_{1} \times \mathrm{F}_{2} \times \mathrm{l}=0.192324 \times 274.13 \times 4.82=254.12 \mathrm{kN} . \mathrm{m}
$$

$$
\begin{gathered}
\mathrm{b}=\frac{\mathrm{h}_{\mathrm{c}}+\mathrm{h}_{\mathrm{l}}}{2}=\frac{0.05+0.21}{2}=0.13 \mathrm{~m} \\
\mathrm{l}_{1}=1.225 \mathrm{~m},
\end{gathered}
$$

$\mathrm{a}=$ width of the beam $-2 \times \mathrm{b}=0.4-2 \times 0.13=0.14 \mathrm{~m}$

$$
\mathrm{M}_{4,2}=\mathrm{M}_{4,1}\left(\frac{\mathrm{l}_{1}-\left(\mathrm{b}+\left(\frac{\mathrm{a}}{2}\right)\right)}{\mathrm{l}_{1}}\right)=254.12\left(\frac{1.225-(0.13+0.07)}{1.225}\right)=212.63 \mathrm{kN} \cdot \mathrm{m}
$$

$$
A_{s}=\frac{M_{4,2}}{z ~ f_{y k}}=\frac{212.63}{0.217 \times 500000}=0.001956 \mathrm{~m}^{2}=19.56 \mathrm{~cm}^{2}
$$

\section{Verification of $\rho 1$}

$$
\rho_{1}=\frac{A_{s}}{b_{w} d}=\frac{19.56}{44 \times 23} \cong 0.02 \Rightarrow \rho_{1}=0.02
$$

Therefore, the iterative calculation for the reinforcement ratio, besides adequately working, was limited to the value of 0.02 .

\section{Table 14 - Calculation of the cracking moment $\left(M_{\mathrm{r}}\right)$ and its corresponding force $\left(F_{2}\right)$}

\section{Section}

\section{Equation}

$$
\begin{gathered}
\mathrm{M}_{\mathrm{r}}=\frac{\alpha \mathrm{f}_{\mathrm{ct}} \mathrm{I}_{\mathrm{C}}}{\mathrm{y}_{\mathrm{t}}} \\
\mathrm{M}_{\mathrm{r}}=\frac{1.5 \times 2896 \times 0.0024}{0.1143} \\
\mathrm{M}_{\mathrm{r}}=91.21 \mathrm{kN} . \mathrm{m}
\end{gathered}
$$

Topping

$$
\begin{gathered}
\mathrm{M}_{\mathrm{r}}=\mathrm{M}_{4,2} \Rightarrow \mathrm{M}_{4,1}=\mathrm{M}_{4,2} \times \frac{1.225}{1.025}=91.21 \times \frac{1.225}{1.025} \\
\mathrm{M}_{4,1}=109.01 \mathrm{kN} . \mathrm{m} \\
\mathrm{M}_{4,1}=\mathrm{k}_{1} \mathrm{~F}_{2} \mathrm{l}=0.192324 \times \mathrm{F}_{2} \times 4.82 \\
109.01=0.192324 \times \mathrm{F}_{2} \times 4.82 \\
\mathrm{~F}_{2}=117.59 \mathrm{kN}
\end{gathered}
$$


The case in which the simple support condition exhibited a failure force greater than that for the continuity condition (span $=3.75 \mathrm{~m}$ ) indicates that continuity is not favorable for this span. However, it is possible that the continuity condition is the solution implemented in the project, even with a decrease in efficiency $\left(F_{2} / F_{1}\right)$, in terms of controlling displacements or vibration, for verifying serviceability limit states.

\section{Acknowledgements}

To CAPES - Coordination for the Improvement of Higher Education Personnel (Coordenação de Aperfeiçoamento de Pessoal de Nível Superior) - for the doctoral scholarship granted to the first author. To Brazilian Association of Industrialized Concrete Construction (ABCIC - Associação Brasileira da Construção Industrializada de Concreto) - and the company LATTICE SLAB (LAJE TRELIÇADA) IND. and COM. LTDA. for providing the hollow core slabs units used in this work. To the friends who collaborated with the experimental test: Thomaz Mendes Lopes Vaz, Bruna Catoia and Fernando Menezes de Almeida Filho.

\section{References}

[01] PET CIVIL - UFJF. Electronic publishing. Available in: <http://blogdopetcivil.com/2011/08/18/lajes-alveolares/>. Accessed on May 2011.

[02] SCHOKBETON INC. Quebec, Canada. Electronic publishing. Available in: <http://www.schokbeton.com/ eng/dalles.html>. Accessed on May 2011.

[03] PRECAST/PRESTRESSED CONCRETE INSTITUTE.PCI. Manual for the design of hollow core slabs. 2.ed. Chicago, IL, USA, 1998.

[04] FÉDÉRATION INTERNATIONALE DE LA PRÉCONTRAINTE (FIP). Planning and design handbook on precast building structures. London, England, 1994.

[05] COSTA, O. O. Avaliação de desempenho de elementos de lajes alveolares protendidas pré-fabricadas. 2009. 132p. Dissertation (Master in Civil Construction) Department of Civil Engineering, Federal University of Sao Carlos, Sao Carlos, SP, Brazil, 2009.

[06] RESENDE, R. S.; GASTAL, F. P. S. L. Análise numérico-experimental de lajes pré-moldadas protendidas com continuidade posterior por adição de sobrecamada de concreto armado. In: Congresso Brasileiro do Concreto, 41 - IBRACON. Salvador. Sept-Oct. 1999.

[07] BARBIERI, R. A.; GASTAL, F. P. S. L. Análise numérico-experimental de elementos pré-moldados protendidos com continuidade posterior por adição de armadura. In: Congresso Brasileiro do Concreto, 41 - IBRACON. Salvador. Set-Oct. 1999.

[08] TAN, K.; ZHENG, L.; PARAMASIVAM, P. Designing hollow core slabs for continuity. PCI Journal. Precast/ Prestressed Concrete Institute, Chicago, IL, USA. v.41, n.1, p.82-91, Jan-Feb. 1996.

[09] PETRUCELLI, N. S.; CARVALHO, R. C. O uso de continuidade em pavimentos com lajes alveolares protendidas. In: Congresso Brasileiro do Concreto, 52 - IBRACON. Fortaleza. Oct. 2010.
[10] PETRUCELLI, N. S. Considerações sobre projeto e fabricação de lajes alveolares protendidas. 2009. 103p. Dissertation (Master in Civil Construction) Department of Civil Engineering, Federal University of Sao Carlos, Sao Carlos, SP, Brazil, 2009.

[11] CATOIA, B. Lajes alveolares protendidas: cisalhamento em região fissurada por flexão. 2011. Thesis (Doctoral in Structural Engineering) - Scholl of Engineering of Sao Carlos, University of Sao Paulo, Sao Carlos, 2011. [12] ASSOCIAÇÃO BRASILEIRA DE NORMAS TÉCNICAS. NBR 6118: Projeto de estruturas de concreto.Rio de Janeiro, 2003.

[13] ASSOCIAÇÃO BRASILEIRA DE NORMAS TÉCNICAS. NBR 14861: Laje pré-fabricada - painel alveolar de concreto protendido - Requisitos e procedimentos. Rio de Janeiro, 2011. 